\title{
Multimodality of Interior Monologues in Faulkner's Stream-of-Consciousness Novels
}

\author{
LIU Shuyun \\ University of Shanghai for Science and Technology, Shanghai, China
}

\begin{abstract}
Interior monologues are common devices across the range of dramatic media (plays, films, etc.), and also effective approaches in novels, especially used interchangeably with stream-of-consciousness in modernist psychological novels. William Faulkner employs several modes of them, encompassing direct interior monologue, soliloquy, and omniscient description in his stream-of-consciousness masterpieces The Sound and the Fury and As I Lay Dying to mirror consciousness at different levels. This paper attempts to differentiate these modes and analyze their respective effects in representing the subtle movements of the psyche processes, thus giving a glimpse of Faulkner's highly skilled craft of capturing and preserving the complicacy and fluidity of consciousness.
\end{abstract}

Keywords: stream-of-consciousness novels, direct interior monologue, soliloquy, omniscient description

Every novelist who tries to present characters in depth faces the problem of conveying, in a convincing way, events in his characters' inner lives which, if they occurred in a real-life situation, would remain forever beyond the knowledge of an outside observer. (Bickerton, 1967, p. 229)

Especially for the 20th century psychological novelists, it has been a constant challenge to faithfully represent the dynamic psychic life freely flowing in a chronological continuum. Numerous novelists have tried various means in this respect, among whom, the American writer William Faulkner was widely accepted as one of the most outstanding figures.

\section{Modes of Interior Monologues}

Robert Humphrey lists four basic techniques used in rendering inner psyche: direct interior monologue, indirect interior monologue, soliloquy, and omniscient description (Humphrey, 1954, p. 28).

Generally speaking, direct interior monologue is the direct first-person narration devoid of the author's interference, that is, without any explanations or remarks from the author on the character's thoughts and experiences. The character is allowed to display his/her inner conflicts, the impressions, emotions, thoughts, associations, etc., that impinge upon his/her mind, therefore more often than not revealing his/her unconsciousness. While with regard to indirect interior monologue, the third-person narration is adopted with the author partly involved to make explanations or comments. So, the subconscious or conscious mind is shown since there is the author's secret control on the movements of the character's inner life. Soliloquy, however, is a speech uttered by the character to reveal "his or her inner thoughts and feelings to the audience, either in supposed self-communion or in a consciously direct address.” (Baldick, 2000, p. 207). That is to say, a

LIU Shuyun, Master's degree in literature, lecturer, Foreign Languages College, University of Shanghai for Science and Technology, Shanghai, China. 
character says to himself or herself, relating a more organized sequence of rational thoughts and feelings in a logical and connected manner. At last, the omniscient description is given by the omniscient powerful author "from an outside, godlike point of view" (Bickerton, 1967, p. 229). Compared with the former ones, it seems to be a more traditional method.

\section{Direct Interior Monologue-Idiot Consciousness \& Dream Consciousness}

If Joyce has a preference for direct interior monologue, and Woolf for indirect interior monologue, then William Faulkner shows a leaning towards a blending one. In The Sound and the Fury (1929) and As I Lay Dying (1930), his stream-of-consciousness masterpieces, Faulkner employed a combination of them to depict consciousness on various levels.

In the first two sections of the novel The Sound and the Fury, direct interior monologues are used to render "the most intimate thought that lies nearest the unconscious" (Humphrey, 1954, p. 24). They represent the meandering of the consciousness of the idiot Benjy and "dream consciousness," or more precisely, day-dream consciousness, of Benjy's brother Quentin before his suicide. Here, consciousness is presented to the reader "with negligible author interference and with no auditor assumed" (Humphrey, 1954, p. 25). The author with his guiding "he saids" and "he thoughts" disappears completely or almost completely from the page, the reader is given a private world, with no visible guide to direct him. Following is such an example used by Faulkner to present Quentin's consciousness in his last minutes:

A quarter-hour yet. And then I'll not be. The peacefullest words. Peacefullest words. Non fui. Sum. Fui. Non sum Somewhere I heard bells once. Mississippi or Massachusetts. I was. I am not. Massachusetts or Mississippi. Shreve has a bottle in his trunk. Aren't you even going to open it Mr. and Mrs. Jason Richmond Compson announce the Three Times. Days. Aren't you even going to open it marriage of their daughter Candace that liquor teaches you to confuse the means with the end. I am. Drink. I was not.... (Faulkner, 1995, p. 173)

In this direct interior monologue, the author has disappeared entirely. It is in first-person, the tense is, willy-nilly, past, present, or future as Quentin's mind dictates; broken sentences or overlapping phrases and sentences are listed; and there are no commentaries, no stage directions from the author. Thus, the unuttered consciousness before it is formulated for deliberate speech is faithfully recorded.

\section{Soliloquy-Near-Surface Consciousness}

In the third-section of The Sound and the Fury, Faulkner turns to soliloquy on a surface, communicating level to depict consciousness of Jason, the only sane one among the Compson brothers. Instead of communicating psychic identity as in the first two sections, soliloquy here communicates Jason's emotions and ideas, which are related to a plot and action. Since it is "less candid... and more limited in the depth of consciousness" (Humphrey, 1954, p. 36) compared with direct interior monologue, soliloquy is proper to present Jason's level of consciousness close to the surface. Though Jason's psychic content and processes are still represented directly from him to readers without the presence of an author, they seem to be directed to a formal and immediate audience. Thus, his monologue is characterized by a greater coherence.

No doubt, As I Lay Dying is one of the highly successful novels in English, which use the soliloquy to depict the stream-of-consciousness. It is composed entirely of the soliloquies of 15 characters. Obviously, the novel is greatly concerned with those attitudes or feelings that lie on the threshold of consciousness. Take 
Jewel's excerpt as an example, which shows his annoyance at his brother Cash who makes the coffin under the mother's death-room window:

It's because he stays out there, right under the window, hammering and sawing on that goddamn box. Where she's got to see him. Where every breath she draws is full of his knocking and sawing where she can see him saying See. See what a good one I am making for you. I told him to go somewhere else. I said Good God do you want to see her in it. It's like when he was a little boy and she says if she had some fertilizer she would try to raise some flowers and he taken the bread pan and brought it back from the barn full of dung. (Faulkner, 1964, p. 14)

The passage here is definitely more coherent than that of direct interior monologue examined before. But signs of stream-of-consciousness are unmistakable. Such a fragment as "where she is got to see him" indicates the thought as it arrives, just as does the last sentence, with three independent clauses, representing only one image unverbalized in Jewel's consciousness. Thus, soliloquy can be found to achieve greater coherence and more unity as well as a successful combination of interior stream of consciousness with exterior action. Yet Faulkner still blends direct interior monologue with soliloquy, such as the rendering of Vardaman's chaotic inner life when he is in the face of Darl's being sent to Jackson (Section 56).

\section{Omniscient Description-Sane Consciousness}

In the last section of The Sound and the Fury, Faulkner adopts the more conventional omniscient description. What is unusual here is that it is not the common description of the appearance or actions of characters but the presentation of the psychic content and processes of a character by an omniscient author through conventional methods of narration and description.

...And he drove on out of the bells and out of town, thinking of himself slogging through the mud, hunting a team. "And every damn one of them will be at church.” He thought of how he'd find a church at last and take a team and of the owner coming out, shouting at him and of himself striking the man down. "I'm Jason Compson. See if you can stop me. See if you can elect a man to office that can stop me," he said, thinking of himself entering the courthouse with a file of soldiers and dragging the sheriff out. (Faulkner, 1995, pp. 305-306)

The depiction of Jason's consciousness when he pursues his niece Quentin illustrates this technique well. Although employing the conventional third-person description, Jason's consciousness in its unspoken and incoherent state is delineated.

\section{Conclusion}

It is universally acknowledged that consciousness is in its prespeech levels unpatterned and a consciousness by its nature exists independent of action. Maybe that explains why it remains a tough problem for stream-of-consciousness writers to record it. Faulkner shows his brilliancy in his inventive techniques to preserve the seeming privacy of consciousness, to suspend mental content and to represent the fluidity of consciousness. The multimodality of interior monologues, in particular, in his stream-of-consciousness novels helps a lot to disclose consciousness on different levels to the full. It is such strenuous and daring technical experiments in his creation that establishes Faulkner's prominent position on a par with James Joyce and Virginia Woolf in the great tradition of stream-of-consciousness writing.

\section{References}

Baldick, C. (2000). Oxford concise dictionary of literary terms. Shanghai: Shanghai Foreign Language Education Press. Bickerton, D. (1967). Modes of interior monologue: A formal definition. Modern Language Quarterly, 28(2), 229-239. 
Faulkner, W. (1964). As I lay dying. New York, N.Y.: Vintage Books.

Faulkner, W. (1995). The sound and the fury. New York, N.Y.: Vintage Books.

Humphrey, R. (1954). Stream of consciousness in the modern novel. Berkeley: University of California Press. 